\title{
The Contribution of Global Sourcing to the Economic Performance of Organizations: Analysis of the Points of View of the Supply Chain Participants
}

\author{
Nouha Lahiani ${ }^{1}$ (D), Kouami Seli Apedome ${ }^{2}$ D , Joelle Zhu $^{3}$ \\ ${ }^{1}$ Paris Diderot University (France) \\ ${ }^{2}$ Université d'Ottawa (Canada) \\ ${ }^{3}$ École Supérieure de Commerce Extérieure de Paris (France) \\ nouba.labiani@univ-paris-diderot.fr, kapedome@uottawa.ca,joelle.zhu@edu.esce.fr
}

Received: January 2018

Accepted: May 2018

\begin{abstract}
:
Purpose: This paper aims at investigating the reasons for the complex and long lead time from global suppliers that causes inventory shortages. It focuses on supply chain risk management in global sourcing. This study has revealed all the specific risks of a global sourcing project and has provided some solutions for risk management: three-step risk management, safety stock, data sharing and driving supplier performance.
\end{abstract}

Design/methodology/approach: A qualitative study is conducted to propose concrete recommendations on three topics: risk management, safety stock and information sharing. A semistructured survey-guided interview was used to collect related data, and the answers were assessed using syntactic, lexical, thematical and NVivo software analysis.

Findings: This study has revealed all the specific risks of a global sourcing project and has provided some solutions for risk management: three-step risk management, safety stock, data sharing and driving supplier performance.

Originality/value: Through research work, we have noticed that the world of the Supply Chain is constantly evolving and that it is becoming more and more complex. Through these interviews, we have noticed that the role of purchasing is changing differently in each sector.

Keywords: risk management, global sourcing, replenishment, lead time, inventory shortages

\section{Introduction}

In the current business environment, manufacturing companies should be increasingly competitive and flexible (Lahiani, Hani, Triki \& El Mhamedi, 2014). Therefore, a growing number of companies are working with Asian suppliers in order to take advantage of cost reduction in the purchase of raw materials, components, subassemblies and products, especially compared to the French market in which labour costs are comparatively high (Hubert, 2013; Babai, 2005). Several companies have been trying to improve their competitiveness by implementing a global sourcing strategy (Ivanov, Tsipoulanidis \& Schönberger, 2017). However, this approach does not seem to be fully effective, as the long lead time from overseas manufacturers involved in global sourcing risks causing potential inventory shortages. Moreover, this context leads to a complexity of replenishment flows and heightened need for risk management in supply chains. 
This study is concerned with the risk mitigation strategies for long inventory shortages by controlling the replenishment of flows. First, long inventory shortages due to poor risk management of distant supply flows requires control of replenishment flows. This flow management is based on an accurate sharing of information between the various stakeholders of a supply chain. To provide recommendations, we surveyed eleven companies that work with global suppliers without difficulties in inventory management.

We focus on the risk management in global sourcing: how to identify and reduce risks. This study aims to investigate the complex and long lead time from global suppliers, causing inventory shortages. It will focus on risk management in global-sourcing supply chain. The evolution and complexity of supply chain management will be analysed. The current issues faced by all French companies in global sourcing will be studied.

While global sourcing is considered to be a leading competitive advantage, it is also associated with risk factors such as cultural differences, global communication and high inventory levels (Portioli-Staudacher \& Tantardini, 2009).

\section{Related Literature Review}

This study supplements the existing body of research dedicated to risk management in global sourcing. It also provides solutions for inventory reduction in global sourcing. Few authors focus on inventory shortages because despite the abundance of data, there is a long lead time between two orders. Existing solutions focus on better stock management in the global sourcing context. The goal is to find a balance to avoid both stock shortages and excess inventory. The analysis of replenishment flows is presented in the first part and the risk prevention in distant supply in the second.

\subsection{Analysis of Procurements Flows}

Procurement processes take place at the upstream of the company's business: they represent the way to purchase goods and services from the suppliers for storage and use in production and for sale of final products. The concept consists of placing orders to replenish inventory according to demand (Hubert, 2013). Its role is to organize, plan and control all inventories, plan replenishment orders and determine quantities and stock management. Procurement actions influence five determinants of profitability and company competitiveness (Ouedraogo, 2013): product quality, cost price or margin, continuity of production, delivery time (stock and lead time) and flexibility of supply (variability in quantity and quality). The two methods of procurement are internal and external. Internal procurements refer to the industrial production of raw materials such as Kanban and MRP. There are also three methods to launch a production: make-to-stock, make-to-order, make-to-forecast. External procurements refer to the replenishment of final products for stock management such as Economic Order Quantity (EOQ) (Hubert, 2013). Procurement strategies play a role for stock management and for forecast determination. A stock is created for different reasons (Arda, 2008): to absorb a lead time, to deal with uncertainties in the procurement process or the demand or to use an economy of scale related to the procurement system.

Inventory management is frequently treated in the literature. Its role is to define parameters such as policy, objectives, level of stock, procedures, visibility and frequency of sales (Ouedraogo, 2013). The literature describes inventory shortages as the inability of the stock to satisfy the demand of customers in terms of quantities (Arda, 2008; Gimenez \& McIvor, 2016; Hubert, 2013). The major consequences of inventory shortage are the impact on the margin, loss of customers and production slow-down. On the other hand, demand is an important parameter for forecast determination. Companies should collect all information for future demands such as an order or a forecast. However, since demand varies, the forecast calculations such as simple mean and exponential smoothing have been formulated (César \& Richard, 2006; Babai, 2005).

Supply-chain-flows management consists of taking a decision for each step of the supply chain, for example, launch time for each activity of production and transportation times and methods. In the beginning, supply-chainflows management was limited to inventory management and has evolved with the complexification of supply chains (Babai, 2005; Gimenez \& McIvor, 2016). The objectives of this study are to identify, analyse and reduce all the wastes in the procurement processes. Eliminating wastes, however, involves taking the right decisions in the supply chain. According to Babai (2005) and Hubert (2013), all decisions in supply-chain management are classified as strategic (long-term) decisions to define competitive advantage and improvement recommendations for all the 
stakeholders of the supply chain, tactical (medium-term) decisions based on the actual planning models to manage all the upstream and downstream operations in a supply chain, and operational (short-term) decisions to respond to customers' needs. To understand the origin of inventory shortages, we need to analyse the entire process of procurement and determine which activity creates wastes and how to reduce them. Inventory shortages come from poor control of the replenishment flows, caused not only by poor demand estimation but also by a lack of information sharing. The management of supply chain flows is presented in Figure 1 as follows:

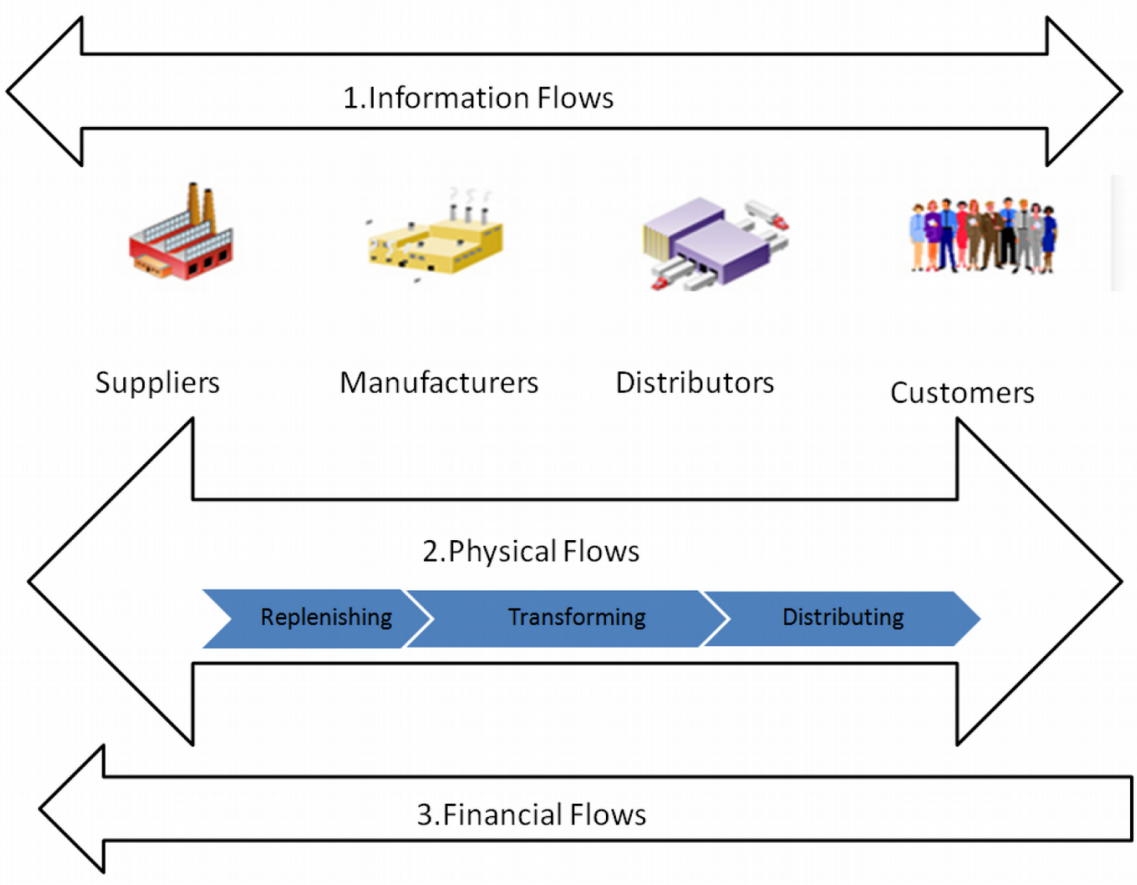

Figure 1. Supply Chain Flows Presentation (Bekkali, 2007)

\subsection{Risk Prevention in Distant Supply}

The literature is rich with works dedicated to motivating companies to implement global sourcing. Typical reasons for global sourcing include finding comparable quality for a lower price, access to new technologies and markets and the unavailability of supplies in the local market (Nunes, Vieira \& Antunes, 2013; Jiang \& Tian, 2009; Portioli-Staudacher \& Tantardini, 2009; Cheraghi, Dadashzadeh \& Subramanian, 2004). The search for alternative sources of supply in foreign markets is considered to be an opportunity for competitive advantage. In Nunes et al. (2013), a successful project of global sourcing implementation in a Brazilian company is presented.

The case analysis is based on the success in the electronic industry of a small Brazilian company that purchased from a distributor but had to be competitive and find global suppliers as it grew fast. This change is also due to the global scope of the industry. To implement global sourcing, however, qualified personnel are required to work in different languages, to participate in negotiations and to overcome barriers. The long learning process leads the company to develop global operations based on the division of the value chain operations in different locations. Nunes et al.(2013) observe that "the use of international suppliers can be a replication of the local supplier practices based on the increase of the total quantity purchased in a search for large suppliers and the reduction of the intermediary companies" (Nunes et al., 2013). The framework thus enabled the researchers to understand how the global sourcing process was conducted by the company. The adoption of global sourcing by companies in emerging economies is an opportunity to expand the knowledge of replenishment. One aspect of the case study is particularly interesting: the capability of the company to analyse its value chain and to define and focus on the activities that would add more value. In this case there were product development and distribution channels. As shown in Table 1, the reasons for global sourcing described in the literature are numerous. 


\begin{tabular}{|l|l|}
\hline \multicolumn{1}{|c|}{ References } & \multicolumn{1}{c|}{ Reasons } \\
\hline $\begin{array}{l}\text { Portioli-Staudacher and Tantardini (2009) } \\
\text { Jiang and Tian (2009) }\end{array}$ & The product is not available in the local country. \\
\hline Portioli-Staudacher and Tantardini (2009) & Same quality as a local supplier \\
\hline Nunes et al. (2013) & $\begin{array}{l}\text { Lower acquisition costs } \\
\text { Lack of local suppliers }\end{array}$ \\
\hline $\begin{array}{l}\text { Portioli-Staudacher and Tantardini (2009) } \\
\text { Jiang and Tian (2009) }\end{array}$ & Economy of scale \\
\hline Jiang and Tian (2009) & Access to new technologies \\
\hline
\end{tabular}

Table 1. Reasons for global sourcing

Although global sourcing is appealing and promising, it is wrongly considered to be risk free. Dittman (2005) suggests three ways to detect supply chain risks in a company: identify, prioritize and mitigate the risks. Gathering data on the current suppliers and on the countries they are located in will be the best way to eliminate the risks. The priority of risks can be done with the tool Failure Mode Effect Analysis (FMEA) to establish some recommended actions and contingency plans. For the next step, mitigation plans need to be developed to manage the top risks by reducing the probability of the frequency and the degree of impact. Strategies which may be used include insurance, competent partners, import excellence, expedited shipping, lean management, six sigma and Supply Chain Event Management (SCEM). The most difficult aspect of risk management is not technical; it is related to the human resources who need to be mobilized to cope with the process of change.

Portioli-Staudacher and Tantardini (2009) carried out a case study on lean Italian companies using global sourcing. This process involves purchasing a large quantity from far away producers, which increases inventories, exposes companies to a higher variability and a lack of flexibility. However, additional risks are created such as communication and logistical issues, political instability, protection of intellectual property, creation of wastes and exchange rate fluctuations (Platts \& Song, 2009; Portioli-Staudacher \& Tantardini, 2009; Hubert, 2013). In today's context of fast-changing markets, to secure a supply chain with lean management is considered an effective solution (Tribune, 2016; Portioli-Staudacher \& Tantardini, 2009). To demonstrate if the implementation of the lean approach may or may not reduce these additional risks, Portioli-Staudacher and Tantardini (2009) carried out 95 telephone surveys with lean companies and selected nine firms to be involved in their case study. The companies selected for the case study have implemented a lean approach for at least three years. The results interestingly indicate that after the introduction of the lean approach, Italian companies did not significantly modify the management of global suppliers, and the communication seems to have not increased after the introduction of the lean approach. Neither the informative flow with global suppliers nor the informative systems used were changed. The author highlights that the long lead time makes companies more dependent on forecasts and increases the bullwhip effect (Chen, Drezner, Ryan \& Simchi-Levi, 1999), which leads to higher inventory levels. However, the authors provided some countermeasures to face the issues: consolidation centers, quality control at supplier locations, milk-run deliveries, use of local supplier next to the global supplier and delivery services.

Global sourcing is generally described in the literature as the best opportunity to reduce the price of components, but this sourcing strategy also has its limits. According to Schiele and Horn (2010), each failed global sourcing project had an "ugly twin," which means that the material not delivered by the new supplier had to be purchased from another supplier, usually the old supplier which was meant to be replaced. A failed global sourcing project results from all the risks neglected: cultural differences, long lead time, logistical issues, lack of flexibility and many intermediaries (Schiele \& Horn, 2010; Hubert, 2013). In Table 2, all the additional risks of global sourcing treated in the literature compared to national sourcing are shown.

It is also interesting to analyse the issue from another point of view: Chinese factories which also had to deal with global sourcing (Jiang \& Tian, 2009). The most relevant example is the lack of experience of the Chinese factories due to their habits of domestic purchasing, weak technological capacity, poor transportation, language differences, customs procedures, and high customer expectations. The inexperienced Chinese manufacturers have to face these 
challenges and should pay more attention to the challenges from logistical capabilities and selecting foreign sources. They should therefore petition the government for the relaxation of protectionist regulations. Khan and Baseer (2016) argue that "managers should also consider elevating the position of their international procurement offices and officers to a more centralized position within the company in order to effectively coordinate international purchasing as part of an overall global strategy". In the context of new global sourcing projects, some cost elements such as those shown in Table 3 should be taken into account (Alard, 2010).

Hubert (2013) is very close to our specific problem, but he tries to reduce stock levels in global sourcing through a comparison between a theoretical calculation of forecast and the HSS forecast calculation of his company. Based on updated and empirical data, the HSS calculation is better than the theoretical calculation because the quantities calculated are the optimal quantities to avoid excess inventories and shortages. Table 4 below presents a synthesis of the literature review that considers the recommendations for risk management in stock shortages in global sourcing.

\begin{tabular}{|c|c|}
\hline References & Risks of global sourcing \\
\hline Hubert (2013) & $\begin{array}{l}\text { - Long lead time } \\
\text { - Defective or late deliveries } \\
\text { - } \text { Less innovation and inferior quality } \\
\text { - Dependence on forecasts } \\
\text { - } \text { Creation of wastes }\end{array}$ \\
\hline $\begin{array}{l}\text { Schiele \& Horn } \\
\text { (2010) }\end{array}$ & $\begin{array}{l}\text { - More intermediaries in the supply chain } \\
\text { - Distance } \\
\text { - Less flexibility } \\
\text { - Logistical issues } \\
\text { - } \text { Cultural differences } \\
\text { - Increased costs }\end{array}$ \\
\hline $\begin{array}{l}\text { Portioli-Staudacher \& } \\
\text { Tantardini (2009) }\end{array}$ & $\begin{array}{l}\text { - Long lead time } \\
\text { - Political instability } \\
\text { - } \text { Communication issues: cultural differences, jet lag } \\
\text { - Logistical issues: transport cost, lack of infrastructure } \\
\text { - Issues with global suppliers: lack of flexibility, lack of industrial culture, } \\
\text { misunderstandings of customers' needs } \\
\text { - Intellectual property: products patented } \\
\text { - }\end{array}$ \\
\hline Platts \& Song (2009) & $\begin{array}{l}\text { - Exchange rate fluctuation } \\
\text { - Political risks } \\
\text { - Cash-flow shortages and paper-work concerns } \\
\text { - Extra cost of travel and communication } \\
\text { - Transportation costs } \\
\text { - Inventory cost tradeoffs due to increased lead-time in the supply chain } \\
\text { - Cultural and linguistic differences }\end{array}$ \\
\hline
\end{tabular}

Table 2. Risks in the global sourcing context

\begin{tabular}{|c|c|c|c|}
\hline Logistical costs & Transaction costs & Capital costs & Risk costs \\
\hline $\begin{array}{l}\text { Packaging } \\
\text { Transportation } \\
\text { Temporary storage } \\
\text { Taxes and duties } \\
\text { Insurance }\end{array}$ & $\begin{array}{l}\text { Vendor sourcing } \\
\text { Initiation } \\
\text { Negotiations } \\
\text { Processing } \\
\text { Adaptation } \\
\text { Control }\end{array}$ & $\begin{array}{l}\text { Investment } \\
\text { Obsolescence } \\
\text { Capital lockup: Transit times } \\
\text { Payment terms } \\
\text { Safety stocks }\end{array}$ & $\begin{array}{l}\text { Unforeseen costs } \\
\text { Insufficient supply availability } \\
\text { Insufficient quality } \\
\text { Insufficient flexibility } \\
\text { Damaged reputation }\end{array}$ \\
\hline
\end{tabular}

Table 3. Costs of global sourcing (Alard, 2010) 


\begin{tabular}{|c|c|c|c|c|}
\hline Reference & Goals & Method & Solution & Results \\
\hline $\begin{array}{l}\text { Hubert } \\
(2013)\end{array}$ & $\begin{array}{l}\text { Reducing stock } \\
\text { levels in global } \\
\text { sourcing and } \\
\text { preserving } \\
\text { service levels }\end{array}$ & $\begin{array}{l}\text { Comparison of PSA's HSS } \\
\text { method (calculation of a } \\
\text { coefficient of flexibility) and } \\
\text { classic stock management } \\
\text { method in the literature }\end{array}$ & $\begin{array}{l}\text { HSS PSA method: flow } \\
\text { control method based } \\
\text { on forecasts and } \\
\text { forecast errors: to secure } \\
\text { supplies based on past } \\
\text { forecast errors for the } \\
\text { supply of distant-stream } \\
\text { PSA }\end{array}$ & $\begin{array}{l}\text { HSS method is better than } \\
\text { conventional methods: HSS is } \\
\text { based on actual empirical data } \\
\text { and updated forecasts, while } \\
\text { the inventory management } \\
\text { method is based on the } \\
\text { normal distribution without } \\
\text { updating the forecast }\end{array}$ \\
\hline $\begin{array}{l}\text { Nunes et al. } \\
(2013)\end{array}$ & $\begin{array}{l}\text { Understand the } \\
\text { adoption process } \\
\text { of globa sourcing }\end{array}$ & $\begin{array}{l}\text { Case analysis on a Brazilian } \\
\text { company which adopted } \\
\text { global sourcing }\end{array}$ & $\begin{array}{l}\text { Analyse framework: } \\
\text { industry, barriers, } \\
\text { dimensions analysis }\end{array}$ & $\begin{array}{l}\text { Effective management of how } \\
\text { global sourcing should be } \\
\text { conducted by a company }\end{array}$ \\
\hline $\begin{array}{l}\text { Schiele and } \\
\text { Horn }(2010)\end{array}$ & $\begin{array}{l}\text { Study of a failed } \\
\text { global sourcing } \\
\text { project: ugly } \\
\text { twins }\end{array}$ & $\begin{array}{l}\text { Secondary data: database of } \\
\text { top } 80 \% \text { automotive } \\
\text { European firms in global } \\
\text { sourcing }\end{array}$ & $\begin{array}{l}\text { Considering all the costs } \\
\text { and barriers for a } \\
\text { potential project in } \\
\text { global sourcing }\end{array}$ & $\begin{array}{l}\text { The unsuccessful projects can } \\
\text { be linked to isomorphic } \\
\text { phenomena: projects were } \\
\text { started with a congenital } \\
\text { defect (complex nature of } \\
\text { global sourcing) }\end{array}$ \\
\hline Alard (2010) & $\begin{array}{l}\text { Analysing costs } \\
\text { of global } \\
\text { sourcing }\end{array}$ & $\begin{array}{l}\text { Survey of } 178 \text { people from } \\
\text { various Swiss companies: } \\
\text { department managers or } \\
\text { board members }\end{array}$ & $\begin{array}{l}\text { Total cost ownership } \\
\text { (TCO) differs } \\
\text { substantially from one } \\
\text { procurement project to } \\
\text { the next and must be } \\
\text { calculated individually in } \\
\text { each case. }\end{array}$ & $\begin{array}{l}\text { Global-sourcing goods from a } \\
\text { low-cost country generates } \\
\text { additional costs on top of the } \\
\text { purchase price. } \\
\text { The respondents apply } \\
\text { different standards in their } \\
\text { assessment of the cost } \\
\text { categories. }\end{array}$ \\
\hline $\begin{array}{l}\text { Jiang and } \\
\text { Tian (2009) }\end{array}$ & $\begin{array}{l}\text { Comparing the } \\
\text { experience of } \\
\text { implementing } \\
\text { global sourcing } \\
\text { between Chinese } \\
\text { and western } \\
\text { companies }\end{array}$ & $\begin{array}{l}\text { Interviews by phone and by } \\
\text { mail with a questionnaire: } 6 \\
\text { Chinese manufacturers } \\
\text { (Auto, Apparel, Furniture, } \\
\text { Computers, Electric and } \\
\text { Toys) }\end{array}$ & $\begin{array}{l}\text { Utilization of third } \\
\text { party logistics (3PL) can } \\
\text { encounter logistical } \\
\text { issues regarding the } \\
\text { motivation of economic } \\
\text { globalization, cultural } \\
\text { differences and } \\
\text { miscommunications that } \\
\text { can be overcome. }\end{array}$ & $\begin{array}{l}\text { Challenges are more serious } \\
\text { for small and medium } \\
\text { companies. Inexperienced } \\
\text { manufacturers should pay } \\
\text { more attention to the } \\
\text { challenges. }\end{array}$ \\
\hline $\begin{array}{l}\text { Portioli- } \\
\text { Staudacher } \\
\text { and } \\
\text { Tantardini } \\
(2009)\end{array}$ & $\begin{array}{l}\text { Implementing a } \\
\text { lean approach to } \\
\text { reduce wastes } \\
\text { created by global } \\
\text { sourcing in } \\
\text { companies }\end{array}$ & $\begin{array}{l}\text { Telephone survey with } 95 \\
\text { lean implementers and } 9 \\
\text { further firms involved } \\
\text { in the case study activity }\end{array}$ & $\begin{array}{l}\text { Consolidation centres, } \\
\text { quality control at } \\
\text { supplier location, milk- } \\
\text { run deliveries, use of } \\
\text { local supplier next to the } \\
\text { global supplier, delivery } \\
\text { services }\end{array}$ & $\begin{array}{l}\text { No significant changes after } \\
\text { integration of lean approach }\end{array}$ \\
\hline Babai (2005) & $\begin{array}{l}\text { Proposing new } \\
\text { stock } \\
\text { management } \\
\text { policy on } \\
\text { forecasting }\end{array}$ & $\begin{array}{l}\text { Comparison of different } \\
\text { flow management policies, } \\
\text { which are stock } \\
\text { management models, where } \\
\text { the demand is expressed as } \\
\text { forecast and uncertainty }\end{array}$ & $\begin{array}{l}\text { Proposing new flow } \\
\text { management policy } \\
\text { based on forecast of } \\
\text { demand, which helps to } \\
\text { manage inventory }\end{array}$ & $\begin{array}{l}\text { Limited to a single product } \\
\text { system }\end{array}$ \\
\hline $\begin{array}{l}\text { Dittman } \\
(2005)\end{array}$ & $\begin{array}{l}\text { Managing risks in } \\
\text { the global supply } \\
\text { chain }\end{array}$ & $\begin{array}{l}\text { Tabulated data from the } \\
\text { responses of over } 150 \\
\text { different supply chain } \\
\text { executives and in-depth, } \\
\text { face-to-face interviews with } \\
\text { senior executives from six } \\
\text { prominent companies }\end{array}$ & $\begin{array}{l}\text { Three steps to risk } \\
\text { management: identify, } \\
\text { prioritize and mitigate }\end{array}$ & $\begin{array}{l}\text { Companies mainly use } \\
\text { insurance companies to } \\
\text { mitigate risks. } \\
\text { Few supply chain } \\
\text { professionals use risk } \\
\text { assessment and risk mitigation } \\
\text { plans. }\end{array}$ \\
\hline
\end{tabular}




\begin{tabular}{|c|c|c|c|c|}
\hline Reference & Goals & Method & Solution & Results \\
\hline Cao (2015) & $\begin{array}{l}\text { Long-distance } \\
\text { procurement } \\
\text { planning in } \\
\text { global sourcing }\end{array}$ & $\begin{array}{l}\text { Demand prediction } \\
\text { techniques and } \\
\text { procurement optimization } \\
\text { methods }\end{array}$ & $\begin{array}{l}\text { Suggestion for an } \\
\text { adaptation framework } \\
\text { for distant supply } \\
\text { planning }\end{array}$ & $\begin{array}{l}\text { Near-optimal approaches have } \\
\text { been used to make } \\
\text { procurement plans while } \\
\text { minimizing the costs of } \\
\text { ordering, storage and } \\
\text { disruption. }\end{array}$ \\
\hline $\begin{array}{l}\text { Kauppi, Salmi } \\
\text { and You } \\
(2017)\end{array}$ & $\begin{array}{l}\text { Compiling a } \\
\text { literature review } \\
\text { about the specific } \\
\text { features that } \\
\text { characterize } \\
\text { supply } \\
\text { management in } \\
\text { Africa by } \\
\text { conducting a } \\
\text { systematic review } \\
\text { of the literature } \\
\text { on sourcing in } \\
\text { Africa }\end{array}$ & $\begin{array}{l}\text { An analysis of } 57 \text { articles } \\
\text { that use a thematic } \\
\text { approach }\end{array}$ & $\begin{array}{l}\text { Identification of key } \\
\text { findings, research } \\
\text { challenges and } \\
\text { opportunities }\end{array}$ & $\begin{array}{l}\text { Four areas that distinguish the } \\
\text { sourcing context in Africa: } \\
\text {-African culture and ethics } \\
\text {-the role of African countries } \\
\text { and suppliers in value-added } \\
\text { global chains } \\
\text {-an increasing emphasis on } \\
\text { sustainability } \\
\text {-the gradual development of } \\
\text { professional procurement } \\
\text { practices }\end{array}$ \\
\hline $\begin{array}{l}\text { Jia, Orzes, } \\
\text { Sartor and } \\
\text { Nassimbeni } \\
(2017)\end{array}$ & $\begin{array}{l}\text { Development of } \\
\text { a conceptual } \\
\text { framework for } \\
\text { global sourcing } \\
\text { strategy }\end{array}$ & $\begin{array}{l}\text { Analysis of the } \\
\text { methodologies of } 52 \\
\text { journal articles which focus } \\
\text { on global sourcing strategy } \\
\text { and structure }\end{array}$ & $\begin{array}{l}\text { Development of a } \\
\text { conceptual model } \\
\text { following the analysis in } \\
\text { the previous column }\end{array}$ & $\begin{array}{l}\text { A proposal for a three- } \\
\text { dimensional model of global } \\
\text { sourcing strategy (supply } \\
\text { internationalisation, internal } \\
\text { integration and external } \\
\text { integration) }\end{array}$ \\
\hline
\end{tabular}

Table 4. Existing literature

\section{Case Study}

\subsection{Methodology}

Qualitative methods make it possible to collect the maximum amount of information to respond to a complex problem. To collect qualitative data, the literature presents three types of interviews: structured interviews (set survey questions), semi-structured interviews (take the respondent through an interview guide on complex subjects) and unstructured interviews (free debate; the results are very difficult to analyse) (Roche 2009). In this paper, the method of semi-structured interviews was chosen because it is better adapted to respond to a complex problem involving unfamiliar topics. The purpose is to gather the maximum data from the respondents. Generally speaking, interviews with 10 to 100 people are advisable (Roche, 2009). The interviews are conducted using an interview guide which seeks different information without influencing the respondents. The interviewer may have a list of topics to be discussed, which could be helpful for further discussion. The strength of this method is in providing an opportunity for each piece of information to be discussed, so no information is missed. This is neither a fixed questionnaire nor a discussion restricted by time. The advantage of this method is to give the opportunity to the respondent to speak with a large degree of freedom.

The semi-structured interviews should follow these steps: developing an interview guide, determining a fixed list of respondents, setting appointments with the respondents and finally analysing the interviews. An interview guide is composed of different topics, with open questions that interviewees can discuss and debate. It is important to recruit interviewees who have expertise in the relevant fields. These respondents should feel invested in the project and motivated to provide information and solutions.

In Jiang and Tian (2009), six Chinese manufacturers are interviewed. In Portioli-Staudacher and Tantardini (2009), nine firms involved in the case study are interviewed. Ammar, Benaissa and Chabchoub (2016) interview ten officials. In this paper, eleven supply-chain professionals were studied. These interviews lasted between 45 and 60 minutes and were audio recorded. The data collected was submitted to analysis using NVivo, efficient software for qualitative data analysis that can support qualitative and mixed-method research. It provides highlights, coding 
stripes, in-vivo coding, word trees, comparison diagrams, text search and importation of different notes (Gibbs, 2002; Bazeley \& Jackson, 2013). The codification process was conducted by the NVivo software based on our specifications. A set of pertinent elements was identified which had to be analysed according to each specification. For example, in the transcription of the interview, the codification could be "global sourcing." The codification process was required to assure the best use of the information.

Our study is based on the following propositions:

Proposition 1: Information exchange and sharing practices among the partners of the logistics chain improve the control of distant supply flows.

Proposition 2: The development of a security stock reduces the supply risks in global sourcing.

\subsection{The Proposed Interview Guide}

The interview guide developed is composed of four topics:

Topic 1: Risk, identification in long replenishment flows

What do risk and risk management mean?

What is the role of supply chain risk management?

What are the main risks in your company? What is the most important risk to mitigate?

How are these risks identified? Which department should do the risk management?

Are risks more or less significant with a global supplier or a domestic supplier and why?

What is the information to take into account in a risk- management process?

Does risk management have a positive impact on the company's performance?

\section{Topic 2: Sharing information/data}

Do you work with an Electronic Data Interchange (EDI) or another mechanism to share information?

What is the role of an EDI?

Is An EDI necessary in the company?

Who must use an EDI?

How can sharing information between supply chain stakeholders reduce inventory shortages?

Topic 3: Safety stock

Does your company work with a safety stock?

In which situation is a safety stock necessary?

Which department should implement a safety-stock policy?

How can a safety stock shared between supply chain stakeholders reduce inventory shortages?

Which situation do you prefer: inventory shortage or overstock?

Topic 4: various

Do you wish to share any other pertinent information?

\subsection{Research Population}

Before the results are given, we will first introduce the French companies that responded to our interviews.

The interviews were conducted from 06/24/2016 to 07/05/2016, with an average duration of between 45 minutes and 60 minutes. Thirty French firms were contacted for the interview, but only eleven officials representing supply 
chain managers were interviewed. This sample respects the mean time suggested by Roche (2009). The number of interviewees is evaluated as optimal.

The research population was composed mainly of purchasing managers, supply chain managers and category managers of French companies working with global suppliers. Eleven companies from the same industry were contacted by phone and were registered. A preliminary pilot test was done to anticipate difficulties. The interviews were focused on companies in the industry of kitchenware, but also included other industries for comparative purposes. The companies' different sizes enabled us to compare their sourcing strategies. Due to the requirement of participating companies to keep their identities confidential, alphabetical letters were attributed to represent the companies. In Table 5, the company size and interviewers' profiles are presented.

\begin{tabular}{|c|c|c|c|}
\hline Company & Respondent & Company size & Interviewee profiles \\
\hline A & M.M & Big company & Procurement manager \\
\hline B & E.D & Big company & Purchaser \\
\hline C & C.B1 & Small and medium-sized enterprise & Purchaser \\
\hline D & S.T & Big company & Procurement manager \\
\hline E & D.C & Small and medium-sized enterprise & Purchaser \\
\hline F & L.S & Big company & Purchaser \\
\hline G & A.A & Big company & Procurement manager \\
\hline H & C.J & Very small company & Category manager \\
\hline I & C.B2 & Very small company & Purchaser \\
\hline J & A.V & Big company & Category manager \\
\hline K & E.T & Small and medium-sized enterprise & Purchaser \\
\hline
\end{tabular}

Table 5. List of respondents

\section{Experimental Results}

Three elements are essential for the creation of value: risk management, security stocks and monitoring.

\subsection{Organizational Performance Requires Improved Risk Management of External Procurement}

Risk management is the daily routine of all companies buying from outside. However, this notion of risk is perceived differently by the respondents. The specificity of the companies surveyed is that they work mainly with Asia, whether with Chinese, Indian or other suppliers.

The risks involved are the same: quality problems, too-long delivery times and product non-conformities. Only company B has a special service, the "supplier development" service that manages risks in supply chains. This task force checks Coface's (French Insurance Company for Foreign Trade) contact information and financial situation. Once the supplier is included in the panel, an audit is carried out to follow up on the procedures and advocate areas for improvement. In other companies, risk management is generally carried out by buyers, product managers, category managers and suppliers for whom risk management is an integral part of their daily lives. The central question is: are the risks more or less significant with a domestic supplier or a foreign supplier? Two respondents, C and D, face 77 percent less risk with a foreign supplier. According to them, the location of the supplier has no impact since the most important factor is the relationship with the supplier. This reflects the same idea as Größler's (2010) that suppliers are much more internationally engaged, and the relationship between a foreign supplier and a world producer is much stronger than between domestic producers and their suppliers.

We advise companies to set up a dialogue with the supplier to avoid misunderstandings and reduce all types of risks. The other nine respondents responded in a similar manner: a distant supplier causes significant risks associated with time and distance. Only three companies, B, C and $\mathrm{K}$, have a panel of "backup providers" because 
it is not feasible for them to have stock shortages. For example, a chain stop can cost $€ 5000$ for company B. It is interesting to note that company $\mathrm{E}$ works closely with Asian suppliers, but only through intermediaries. This means that the company is in constant contact with another French company, which has to manage the relationship with the Asian supplier, including factory production and quality control. The risks are thus outsourced and the company E does not have to manage them.

Companies $\mathrm{C}$ and $\mathrm{K}$ specialize in the textile sector. From the interviews, we found that they have the same procedure to limit the risks of poor quality: pre-production samples are taken and then analysed before a quality control on the finished product takes place at the end of production. Purchases in the textile sector are distinguished by the fact that they involve seasonal products that sell over short-term periods, such as fall-winter or spring-summer collections. In addition, these two companies use the same method of sourcing: a second source of closer supply is created in the event of a dispute with the main supplier. Both respondents have already faced this type of situation in which the primary supplier becomes a supplier at risk and a second source of supply is developed. Here the principle of "ugly twins" often applies (Schiele \& Horn, 2010), that is, the raw material that could not be supplied by the new supplier had to be purchased from another supplier, which often turns out to be the former supplier that has been replaced.

We used NVivo and compared the comments of respondents $\mathrm{C}$ and $\mathrm{K}$ using source encoding (node creation). The sources correspond to the interviews with the respondents (respondent $\mathrm{C} 78=$ source 3 ).

The encoding corresponds to an assignment of nodes on the comments of our respondents, and the nodes are chosen themes. We find that several identical nodes, such as "permanent product" and "pre-production sample", appear for both companies, thus proving that the vocabulary used and their working methods are the same.

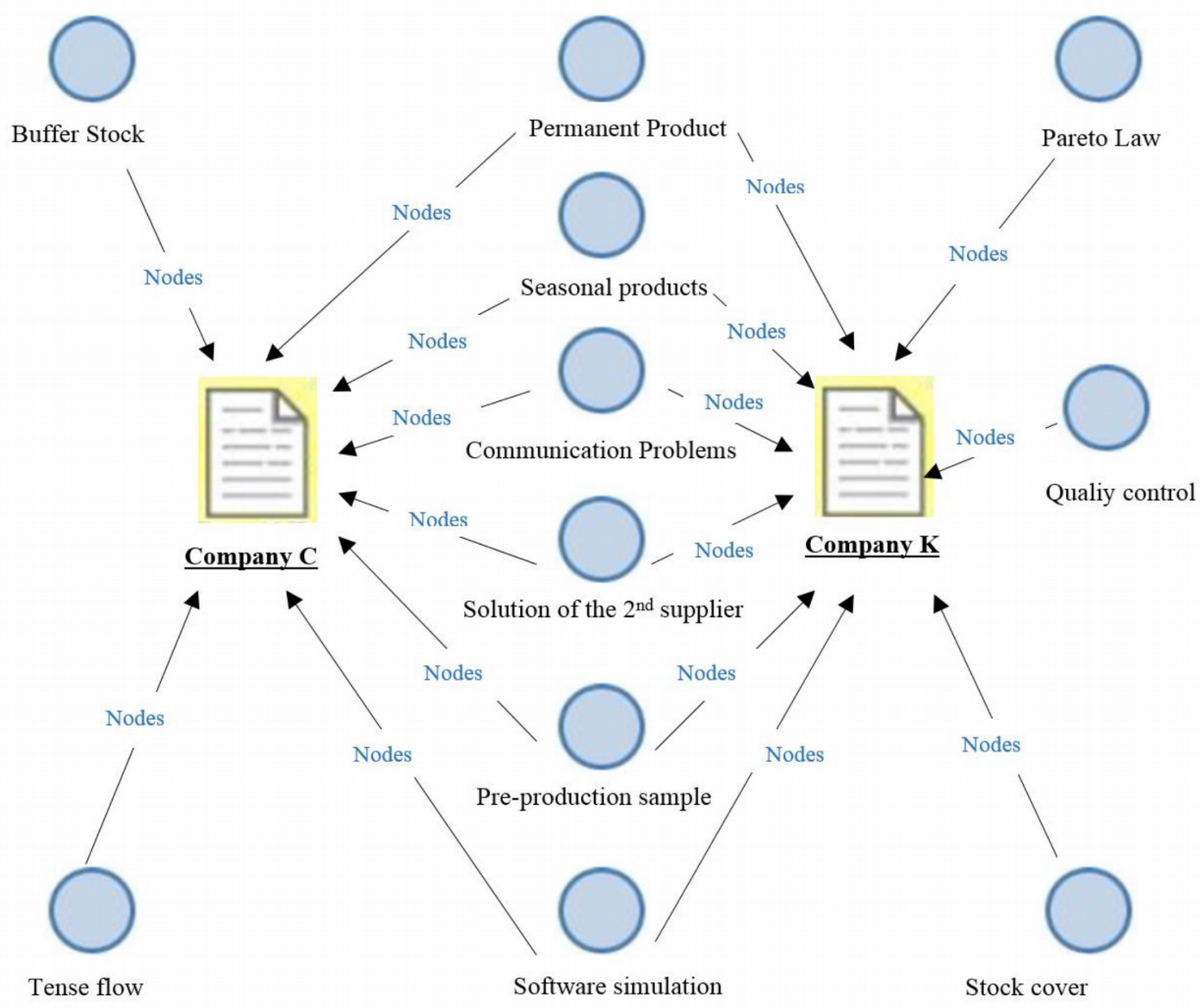

Figure 2. Comparison between company $\mathrm{C}$ and $\mathrm{K}$ by Nvivo 
It is interesting to note that the risks are more likely to appear for new products than for established ones. Since the volumes released are not identical, it is difficult to estimate a sale curve for a new product, so purchases are made a little randomly according to the typology of the product, the sales potential, the market trend, the sales network, or the sales format (per unit, in display). Due to the encoding used on NVivo on the "novelty" node, six respondents out of ten (A, B, E, F, J, I) told us that they encountered difficulties with each launch of new products.

Analysis of interview results showed that risks are greater for new products. In order to limit these risks, the sales history of similar products would be helpful. If no similar product is available, it is possible to order only MOQ or to negotiate a lower MOQ with the supplier in order to facilitate the product's market entry.

The inflexibility of external suppliers is a difficult obstacle to overcome. Indeed, factories did not foresee the arrival of global sourcing and had to learn to work with Chinese factories which lack a common industrial culture (Jiang \& Tian, 2009). Collaboration between Chinese and French companies is challenging: specifications often do not match the capabilities of supplier s, and misunderstandings are common.

Transparency of communication is crucial in order to avoid surprises with suppliers because hidden information could lead to serious adverse consequences. For example, if an Asian supplier outsources a component elsewhere, that outsourcing adds an additional but hidden risk which could complicate or undermine improvement plans.. There may be problems with tools or with parts of the production that are subcontracted, which causes cumulative delays in the production.

Risks in supply chain are often similar (quality, delivery time, etc.) and must be understood by buyers when selecting suppliers. Independent risks such as the parity of the euro and the dollar or natural disasters are more difficult to manage.

We recommend that companies implement the three risk-management steps of Dittman (2005), that is, identify, prioritize and mitigate risks. It is possible to start by collecting different risk data, classifying them and creating the most urgent risk- reduction plans, in collaboration between the offices of the countries concerned.

\subsection{Organizational Performance Requires Better Management of The Security Stock}

We find that all companies surveyed have set up a security stock in their own way, except for company A which specialized in luxury goods. The purchasing policy of respondent A is to create stock shortages in order to stir up demand for luxury goods, while company $\mathrm{G}$ is a wholesaler and its purchasing policy is to have a large stock. Some have set up a security stock only on permanent product references that have a good sales turnover, whereas this is not the case for seasonal products. Other respondents rely on buffer stocks, that is, products in production. We have created two nodes in NVivo "buffer stock" and "warehouse security stock", which we encoded according to the information from each respondent. We also noticed that it was usually the big companies that have set up a security stock in warehouses (D, F, G, J).

It is interesting to note that $G$ is a wholesaler with more than 16,000 product references to manage, and its procurement policy is to always buy products in large quantities, regardless of customer's predictions and the profile of the product. Over-stocking is part of their policy, so suppliers have never experienced stock-outs. Regarding the calculation of the security stock, it is the same for the respondents: to respect a minimum stock and a maximum stock, and never to exceed the two thresholds. The goal is to find a "balance", a term often heard. Five out of ten respondents (B, C, D, E, F) use software that sets up alerts of potential stock shortages, thus making it possible to better anticipate stock shortages.

Two respondents out of eleven (D and $\mathrm{K}$ ) advocated putting in place a security stock according to methods already existing in Supply Chain such as the ABC ranking or the Pareto law. The principle remains the same: to favor the stock on the references of products with high rotations. 


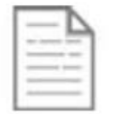

C.B.2. (Company I, Table Art sector)

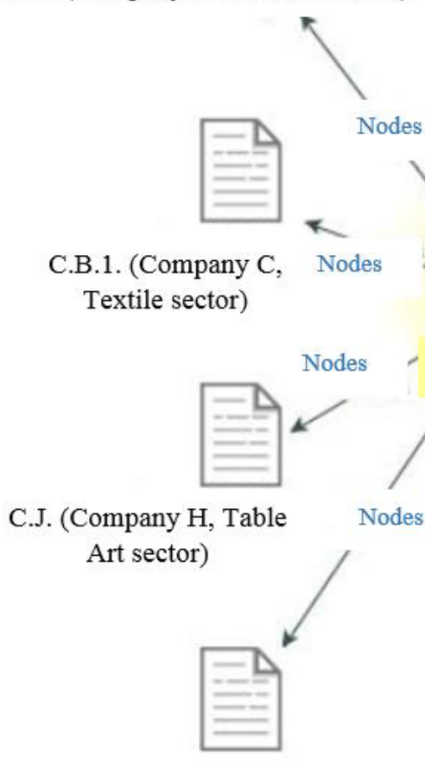

E.T. (Company K, Textile sector)

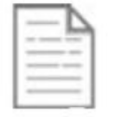

E.D. (Company B, automotive industry)

A.A. (Company G, Table Art sector)

Figure 3. Encoding of the "buffer stock" and "warehouse stock" nodes under NVivo software

The idea of a safety stock is considered to be the most effective solution to avoid stock-outs by each respondent. All interviewees said that they preferred to be overstocked than out of stock, especially on important permanent products. During the interviews, we felt heightened attention among supply chain professionals regarding product profiles (permanent, seasonal, promotional, etc.)

This is a parameter to be taken into account in order for the entire supply chain to understand product sales and to be able to anticipate future purchase orders.

It should be noted that company B has a particularity regarding its stock management: it has consignment stock. This alternative makes it possible to have a stock available without necessarily using it immediately. This is beneficial because overstocking creates an additional cost of product storage, and being out of stock leads to a loss of turnover.

The analysis of these interviews suggests that companies operating in same context must put in place a stock of security on product references with a strong turnover of sales.

In this case, one parameter to take into account is the minimum of quantity (MOQ) required by Asian suppliers. If the MOQ is too high, storage cost will become excessive. If the MOQ is too high and the company is waiting for stock warehouse supply to drop to avoid overstocking, lead time is not to be neglected because it is possible to fall out of stock easily during the supply period. For example, for the end-of-year sales that are most important, it is possible to set up an exceptionally safe stock.

\subsection{Organizational Performance Requires Effective Communication}

Not all companies work with EDI; only three respondents (B, D, F) out of eleven works in EDI with their supplier. Most use in-house software to exchange information, gain insight into inventory, generate sales and anticipate purchase orders. Companies D and F have an EDI internally and have also created a special EDI with big suppliers, in which the information is better managed because the supplier is much more responsive. We note that these are the only two companies in the household appliances business that share the information with the supplier. 
Interestingly, respondents $\mathrm{E}$ and $\mathrm{J}$ believe that $\mathrm{EDI}$ is not the solution to the problem but that it plays a support or tool role in helping to reduce stock-outs.

We note that these are large corporate structures that have implemented an EDI, so there is a link between the implementation of an EDI and the size of the company. Respondent I pointed out that only retailers like Carrefour, Auchan or Walmart can work with EDI.

Six out of eleven respondents (C, E, H, I, J, K) think that it is difficult to implement a special EDI with the supplier because the product profiles are different: some products are permanent where sales are made throughout the year and others are seasonal. Respondents from companies $\mathrm{E}$ and $\mathrm{F}$ believe that EDI must become mandatory in all 82 companies because the exchange of information by the computer has become indispensable for the performance of the company.

Respondents from companies B and C have similar points of view in the sense that EDI should be implemented in companies with a large number of suppliers and a large reference quantity of products to be managed. The fact that the orders are generated automatically by the system with the necessary information (time of supply, price, minimum of quantity (MOQ), etc.) simplifies the process, avoiding overstocking and immobilizing money. If there are concerns about purchase orders, it is possible to manually intervene with the system and modify the orders. Although EDI can automate procedures and streamline information, human surveillance is still needed.

Company B, which specializes in the automotive sector, is the only company to use Materials Requirements Planning (MPR), a computerized production management system, processed by Hubert (2013). Indeed, the nomenclature is managed with the product tree for the industrial part. The role of purchasing is to put prices for each component (MOQ, supply time, etc.) and to make the link with the logistics (it is necessary to order/anticipate in advance according to the delivery time). This information is filled out months in advance. Logistics puts management data, match the needs of customers, and looks into the nomenclature to determine how many components they need. Then, the MRP calculates the need with an open command: automatically sending it to the supplier. It is then necessary to wait until the weekend for the MRP to update.

Exchanges of computer data have been in existence for more than twenty years, whether in the form of sending Excel files or by software, information always passes between a supplier and a customer.

Feedback on EDI has all been the same: it is an effective interface for internally sharing information that sheds light on different product movements, but it is not necessarily a solution as such to avoid stock outs. EDI is no longer considered a useful tool.

It is useful to implement a better EDI only internally. While this is not the ultimate solution to the supply problem, it helps to solve it. Indeed, EDI will remain a support tool, and in order to avoid long stock-outs, communication between suppliers and customers must be much more lively and transparent. Only companies B and F can set up an EDI with the supplier in the form of a module if their information system is compatible, where the supplier can consult customers' stock without intervening and launch production based on this information.

There is a relation between company structure and the performance of the EDI. If the structure is large, the technical resources that go with it are more important and the corresponding computer system should be much more efficient. In our current case, we cannot work with Asian suppliers using modules because technical resources are quite limited. In addition, setting up an EDI that gives access to our inventory also represents a risk. This implementation must be based on a very high level of trust because a supplier is no longer just a supplier ; that supplier becomes a partner.

However, it is possible to set up an interface/EDI specifically for customers in order to collect their forecasts in advance and to anticipate purchase orders.

\section{Conclusion}

With an increasingly globalized economy, global sourcing has evolved considerably in recent years. This particular environmental context creates complex flows and risk management challenges. The main objective of this paper has been to suggest solutions for stock management in global sourcing with a real case-study. From the analysis of 
semi-directive interviews, we have shown that the establishment of an EDI and a security stock in a company working in global sourcing would reduce the risks in the supply chain, but not to the point of eliminating those risks.

The control of risk management in the supply chain has a positive impact on a company's performance because it makes it possible to provide rapid solutions to the additional risks of global sourcing if a risk reduction plan is created. Throughout this study, we have noticed that the field of the supply chain is constantly evolving and that it is becoming more and more complex. From the analysis of the interviews in this study, we identified the role of purchasing changes in each sector. As a limitation to this research, we will mention the small sample size and the fact that we have limited our analysis to three areas of focus: risk management associated with lead time, security stock and implementation of EDI. In a future study, it would be productive to conduct this research in a different geographic context and/or with a larger sample.

\section{Declaration of Conflicting Interests}

The authors declared no potential conflicts of interest with respect to the research, authorship, and/or publication of this article.

\section{Funding}

The authors received no financial support for the research, authorship, and/or publication of this article.

\section{References}

Alard, R. (2010). The costs of global sourcing. Nature, 439(26), 374-375.

André, T. (2016). Piloter la performance fournisseurs pour sécuriser sa logistique. Supply Chain Magazine, 102, 153.

Ammar, M.H., Benaissa, M., \& Chabchoub, H. (2016). Preliminary Study on Stakeholders' Needs and Requirements in the Development of a Traceability System for Road Transport of Crude Oil. IEEE International Conference on Advanced Logistics and Transport (ICALT). At Krakow, Polond.

Arda, Y. (2008). Politiques d'approvisionnement dans les systèmes à plusieurs fournisseurs et Optimisation des décisions dans les chaînes logistiques décentralisées. Thèse de doctorat en Systèmes industriels, Institut National des Sciences Appliquées de Toulouse.

Babai, M.Z. (2005). Politiques de pilotage de flux dans les chaines logistiques: impact de l'utilisation des previsions sur la gestion des stocks. Thèse de doctorat en Génie Industriel, Ecole Centrale Paris.

Bazeley, P., \& Jackson, K. (2013). Qualitative data analysis with NVivo. Sage Publications.

Bekkali, M. (2007). Quand le Marketing fait appel au Supply Chain Management. Point de vue Marketing du 12 october 2007. https://pointdevuemarketing.wordpress.com/2007/10/12/quand-le-marketing-fait-appel-au-supply-chain-management \% $2 \% 80 \% \mathrm{a} 6 /$

Cao, Y. (2015). Long-distance procurement planning in global sourcing. Chemical and Process Engineering. Ecole Centrale Paris.

César, E., \& Richard, B. (2006). Les Séries Temporelles, 1-34.

Chen, F., Drezner, Z., Ryan, J. K., \& Simchi-Levi, D. (1999). The bullwhip effect: Managerial insights on the impact of forecasting and information on variability in a supply chain. Quantitative Models for Supply Chain Management, 17, 417-439. https://doi.org/10.1007/978-1-4615-4949-9_14

Cheraghi, S.H., Dadashzadeh, M., \& Subramanian, M. (2004). Critical success factors for supplier selection: An update. Journal of Applied Business Research, 20(2), 91-108.

Dittman, J.P. (2005). Managing risk in the global supply chain. Game-Changing Trends in Supply Chain, 231.

Gibbs, G. (2002). Qualitative data analysis: Explorations with NVivo (understanding social research). Buckingham. 
Gimenez, C. \& McIvor, R. (2016). Risk, risk management practices, and the success of supply chain integration. International Journal of Production Economics, 171, 361-370. https://doi.org/10.1016/j.ijpe.2015.03.020

Größler, A. (2010). An Exploratory Study of Differences in Manufacturing Strategy between National and Global Production Firms. Journal of Management and Strategy, 1(1), 47-63. https://doi.org/10.5430/jms.v1n1p47

Hubert, T. (2013). Prévision de la demande et pilotage des flux en approvisionnement lointain. Thèse de doctorat en Génie Industriel, Ecole centrale Paris.

Ivanov, D., Tsipoulanidis, A., \& Schönberger, J. (2017). Basics of Supply Chain and Operations Management. Global Supply Chain and Operations Management. Springer International Publishing., 1-14. https://doi.org/10.1007/978-3319-24217-0_1

Jia, F., Orzes, G., Sartor, M. \& Nassimbeni, G. (2017). Global sourcing strategy and structure: Towards a conceptual framework. International Journal of Operations \& Production Management, 37(7), 840-864.

https://doi.org/10.1108/IJOPM-09-2015-0549

Jiang, C. \& Tian, Y. (2009). Problems and challenges of global sourcing: A study of Chinese manufacturing enterprises. Mémoire de master en Business Administration, Jonkoping University.

Kauppi, K., Salmi, A., \& You, W. (2017). Sourcing from Africa: a systematic review and a research agenda. International Journal of Management Reviews, 20(2), 627-650.

Khan, M.A. \& Baseer, M. (2016). Globalization of Logistics and Supply Chain Management. Supply Chain Management.

Lahiani, N., Hani, Y., Triki, A., \& El Mhamedi, A. (2014). Multiobjective Optimization Approach to Solve a Maintenance Process Problem. 3dr Stochastic Modeling Techniques and Data Analyses International Conference SMTDA'14 (397-404). Lisbon, Portugal.

Nunes, M., Vieira, L., \& Antunes, J. (2013). The adoption of Global Sourcing by a Brazilian Company. Journal of Operations and Supply Chain Management, 6(2), 114-127. https:/ / doi.org/10.12660/joscmv6n2p114-127

Ouedraogo, Z. (2013). Analyse des risques liés à l'approvisionnement en matières premières dans une entreprise industrielle: Cas de Winner Industrie (Burkina Faso). Master professionnel de comptabilité et gestion financière, Institut supérieur de comptabilité, de banque et de finance.

Platts, K., \& Song, N. (2009). The true costs of overseas sourcing. POMS 20th Annual Conference (1-26).

Portioli-Staudacher, A., \& Tantardini, M. (2009). Global Sourcing: Lessons from lean companies to improve supply chain performances. 3rd International Conference on Industrial Engineering and Industrial Management (1549-1558). Terrassa, Barcelona.

Roche, D. (2009). Réaliser une étude de marché avec succès. Eyrolles.

Schiele, H., \& Horn, P. (2010). The "UGLY TWINS": Failed global sourcing projects and their substitutes. Competitive paper for the 26th IMP conference. Budapest.

Tribune (2016). Piloter la performance fournisseurs pour sécuriser sa logistique. Supply Chain Magazine, $102,153$.

Journal of Industrial Engineering and Management, 2018 (www.jiem.org)

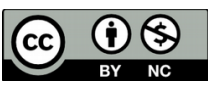

Article's contents are provided on an Attribution-Non Commercial 4.0 Creative commons International License. Readers are allowed to copy, distribute and communicate article's contents, provided the author's and Journal of Industrial Engineering and Management's names are included. It must not be used for commercial purposes. To see the complete license contents, please visit https://creativecommons.org/licenses/by-nc/4.0/. 